\title{
DINAMIKA IJTIHAD ULAMA INDONESIA DALAM FORMALISASI HUKUM ISLAM
}

\author{
Oleh: \\ Muh. Yunan Putra \\ Dosen IAI Muhammadiyah Bima
}

\section{Abstract:}

Indonesia is the one of democracy country and has principle of believe in the One Supreme God. Refer to it, there are some roles or the bills created based on Islamic Law, such as Marriage Law, Heritage Law, Waqf Law and Criminal Law.

In apply, Islamic Low usually face the normative situation and the increasing of human need and thinking. So, it is required to be able to adjust or create new form to fulfill both of interest. In this case, it can be seen at product law or fatwa created by Indonesian Council Of Ulama (MUI) which integrated based on community's need. However, disconnected between structure and function of law caused by political performance. Historically, Islamic Law in Indonesia was influenced by social-culture aspect, it marge with Islamic thinking and characteristic such as Fiqh Book, Islamic roles in Muslim's country, judgment or verdict, or the roles (fatwa) which is created by Ulama. So, namely Islamic Law is the pure of Islamic thinking which produced by Ulama integrated with the social environment. Although, al-Quran dan al-hadits have the roles also to be law, but there are many problems that need to solve using the law's guide. To solve that problems, Ulama do ijtihad and think hard to get out problem solving. Finally, Ulama use their mind to fulfill the emptiness law, so the result is the product of thinking law as now as.

Keywords: Ijtihad, Formalization, Islamic Law.

\section{Pendahuluan}

Ijtihād merupakan suatu metode yang dilakukan oleh para Ulama untuk memperoleh landasan, petunjuk serta legitimasi dalam kehidupan umat manusia, khususnya umat Islam. Umat Islam sendiri telah di akui oleh Allah swt. sebagai umat terbaik (khair ummah), sebagaimana dalam al-Qur'an yang berbunyi: 


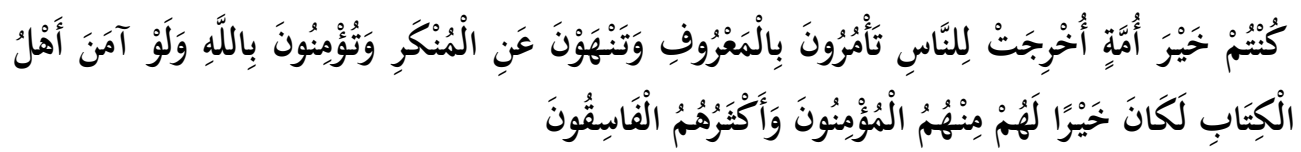

"Kamu adalah umat yang terbaik yang dilahirkan untuk manusia, menyuruh kepada yang ma'ruf, dan mencegah dari yang munkar, dan beriman kepada Allah. Sekiranya ahli kitab beriman, tentulah itu lebih baik bagi mereka, di antara mereka ada yang beriman, dan kebanyakan mereka adalah orang-orang yang fasik. (QS. Āli-Imran/3: 110)."1

Hal tersebut adalah sebuah kabar gembira bagi umat Islam sendiri agar kiranya bangga dan bahagia terhadap apa yang telah Allah legimitasikan kepada mereka. Namun ayat tersebut juga bukan pemberian secara cuma-cuma dan prerogratif, namun lebih merupakan tantangan. ${ }^{2}$ Oleh karena itu responnya bukan bermalas-malas dan tidur lantaran beranggapan sudah ada jaminan. Namun harus bekerja keras untuk mampu mewujudkan amal ma'ruf untuk kemudian pantas mengajak umat kepada yang ma'ruf, dan mampu menghindari kemungkaran untuk kemudian pantas melarang orang lain dari kemungkaran.

Merujuk kepada pengertiannya, ijtihād secara bahasa atau lugawinya; kata ijtihād berasal dari akar kata ijtahada-yajtahidu yang berarti mencurahkan segala kemampuan atau menanggung beban. Oleh karna itu, ijtihād menurut ahli bahasa adalah usaha yang optimal dan menanggung beban berat. ${ }^{3}$ Muhammad Hasbi Al-Șiddieqy menjelaskan bahwa dalam mentakrifkan ijtihād ini, para mujtahidin memberikan berbagai macam arti, ada yang menakrifkannya dengan arti yang sempit dan ada yang menakrifkannya dengan arti yang luas. ${ }^{4}$ Arti yang sempit ialah, arti yang diberikan Syāfi'i, yaitu ijtihād dan qiyāss sama artinya. Sedangkan dalam arti yang luas adalah:

\footnotetext{
${ }^{1}$ Lihat: Khadīm al-Haramain al-Syarifain, Al-Qur'an dan Terjemahan Maknanya, hlm. 94.

${ }^{2}$ A. Qodri A. Azizy, Modern Scientific Ijtihād Bagian Pertama, disampaikan dalam seminar umum, Jakarta, 2010

${ }^{3}$ Muhammad Shuhufi, "Pengantar" Ijtihād dan Fleksibilitas Hukum Islam, (Makassar: Alauddin University Press, 2012), hlm. 11.

${ }^{4}$ Teungku Muhammad Hasbi al-Șiddieqy, Pengantar Hukum Islam, (Semarang, Pustaka Rizki Putra, 1997), hlm. 50

${ }^{5}$ Secara bahasa qiyās berarti ukuran, mengetahui ukuran sesuatu, membandingkan, atau menyamakan sesuatu dengan yang lain. Sedangkan secara istilah, qiyās adalah memberlaukan hukum asal kepada hukum furu' disebabkan kesatuan 'illat yang tidak dapat dicapai dengan pendekatan bahasa saja. Maksudnya, illat yang ada pada satu nash sama dengan 'illat yang ada pada kasus yang sedang dihadapi seorang mujtahid. Karena kesatuan 'illat ini, maka hukum dari kasus yang sedang dihadapi disamakan dengan
} 
a. Ahli Tahqïq mengatakan bahwa: ijtihād ialah qiyās dan mengeluarkan (meng-istinbāt-kan) hukum dari kaidah-kaidah syara' yang umum.

b. Sebagian ulama ușūl menetapkan bahwa: ijtihād adalah mempergunakan segala kesanggupan untuk mengeluarkan hukum syara' dari kitabūllah dan hadis Rasul.

Menurut Muhammad al-Amīn ibn Muhammad al-Muhtār alSyātibi ijtihād adalah:6

بذل الفقيه وسعه بالنظ فى الأدلة لأجل بأن يحصل له الظن او القطع بأن حكم الله فى مسألة

"Usaha seorang ulama fiqh dengan mengerahkan kemampuannya dengan melihat dalil-dalil zanni maupun qat $t^{\prime}{ }^{7}$ untuk menyimpulkan hukum dalam sebuah masalah." Sedangkan menurut Abdul Wahhāb Khalaf, ijtihād adalah:8

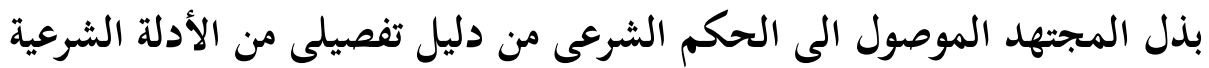

"Mengerahkan kesungguhan untuk memperoleh hukum syara' dari dalil terperinci dengan dalil-dalil syara'."

Maka dari definisi-definisi di atas, dapat ditarik sebuah hakikat atau kesimpulan dari ijtihād adalah sebagai berikut: ${ }^{9}$

a. Ijtihäd adalah pengerahan daya nalar secara maksimal.

b. Usaha ijtihäd dilakukan oleh orang yang telah mencapai derajat tertentu di bidang keilmuan disebut fakih.

c. Produk atau usaha yang diperoleh dari ijtihäd itu adalah dugaan kuat tentang hukum syara' yang bersifat amaliah.

d. Usaha ijtihād ditempuh dengan cara-cara istinbāt.

hukum yang ditetukan oleh nash tersebut. Lihat: Nasrun Haroen, Ușul Fiqih, (Ciputat, Logos Publishing House, 1999), hlm. 62.

${ }^{6}$ Muhammad al-Amīn ibnu Muhammad al-Muhtār al-Syātibi, Muzakkarah Fï Ușūl al-Fiqh, (Madïnah al-Munawwarah, Maktabah al-Ulūm wa al-Hikam, t.th), hlm. 369.

${ }^{7}$ Abdul Wahab Khalaf mendefinisikan qaț'i dalalah yaitu suatu teks yang menunjukkan pada makna tertentu yang dapat dipahami darinya, tidak ada kemungkinan untuk dita'wīlkan, dan tidak ada peluang untuk memahami makna selain dari makna tekstualnya. Seperti firman Allah dalam surat al-Nisā', ayat 12 "dan bagimu (suami) seperdua dari harta yang ditinggalkan oleh isteri-isterimu jika mereka tidak ada anak." Ayat ini menunjukkan qat' $i$, yang berarti suami mesti mendapatkan seperdua, tidak boleh selain ketentuan itu. Maimun, Teori Qaț'i dan zannī Dalam Perspektif Hukum Keluarga Islam, (Makalah Presentasi Dosen Fakultas Syari'ah IAIN Raden Intan Lampung, tidak diterbitkan t.th)

${ }^{8}$ Mardani, Ușūl Fiqh, h. 353-354. Lihat juga: Muhammad Ibn Hussain Ibn Hasan al-Jaizani, Mu'ālim Ușūl al-Fiqh 'inda Ahlu Sunnah wa al-Jamā'ah, (Cet. I, Riyadh, Dār al-Ibn al-Jauzi, 1996), h. 470.

${ }^{9}$ Mardani, Ușūl Fiqh, h. 354 


\section{Peran Ulama Indonesia dalam Penetapan Hukum Islam di Indonesia}

Ulama adalah produk hukum yang harus diakui keberadaan dan hasil ijtihadnya oleh setiap golongan manusia, dalam hal ini umat Islam khususnya. Karena dari mereka inilah segala macam persoalan yang terjadi dan berkembang dalam kehidupan bermasyarakat terpecahkan dan terselesaikan sesuai dengan garis yang telah dibahasakan oleh Alqur'an maupun Hadis.

Oleh besarnya tanggungjawab yang harus dipegang dan ditangguhkan kepada para ulama, khususnya para ulama yang berada dalam ranah negara demokrasi, maka menjadi seorang ulama bukanlah sesuatu yang mudah dan dipilih laksana memilih seorang presiden ataupun gubernur, ulama lahir dan ada ketika mereka telah dianggap memenuhi syarat dalam keilmuan dan persyaratan-persyatratan lainnya. Maka setelah mereka para ulama ini terlahir dan ada, persoalan selanjutnya adalah bagaimana mereka digunakan oleh Negara sehingga bisa turut serta berperan dan turut serta menyelesaikan permasalahan yang ada di tengahtengah masyarakat.

Di Indonesia sendiri Negara memberikan tempat yang layak untuk para ulama tersebut agar bisa turut serta berperan dalam kehidupan masyarakat Indonesia, pemerintah memberikan meja yang disebut Majelis Ulama Indonesia atau yang disingkat MUI. Namun oleh karena Indonesia adalah Negara yang berbentuk demokrasi maka disini ulama dituntut untuk bisa kiranya menyelaraskan antara hukum islam dengan hukum Negara yang berlaku sehingga hukum yang terlahir, tidak hanya dapat dipakai oleh masyakat yang beragama Islam, tapi juga dapat di terima oleh masyarakat yang beragama lain.

Pengembangan hukum Islam, disamping dilandasi oleh epistemologisnya yang kokoh juga perlu memformulasikan dan merekonstruksi basis teorinya. Basis teori hukum Islam sebagaimana dibahas oleh para ahli teori hukum Islam terdahulu, bahwa salah satu persyaratan penting mujtahid dalam melakukan ijtihadnya adalah keharusan mengetahui tujuan ditetapkannya hukum dalam Islam. Pernyataan ini untuk pertama kalinya dikemukakan oleh Abd al-Malik alJuwani, dilanjutkan oleh Abu Hamid al-Gazali, diteruskan oleh Izzuddin ibn Abd al-Salam. Basis teori ini secara sistematis dan rinci dikembangkan oleh Abu Ishaq al-Syatibi dan dileberalisasikan oleh Najamuddin at-Tufi. Kajian utama dalam teori maqasid al-syari'ah adalah mengenai tujuan hukum Islam yang diwujudkan dalam bentuk kemaslahatan umat manusia 
baik di dunia maupun di akhirat. ${ }^{10}$ Oleh karena itu, formulasi dan rekonstruksi peraturan perundang-undangan, tawaran teoritis dan metode ijtihad apapun dalam menyelesaikan persoalan-persoalan hukum Islam harus mengacu pada terwujudnya kemaslahatan tersebut. Tentu yang dimaksud dengan persoalan hukum dalam hubungan ini adalah persoalanpersoalan hukum kontemporer yang menyangkut bidang mu'amalah.

Untuk melihat tingkat keabsahan fatwa-fatwa MUI sebagai bentuk Ijtihad dari segi syari'at diperlukan pengamatan ushul al-fiqh terhadap proses perumusan fatwa-fatwa tersebut. Secara teoritis MUI mempunyai pedoman bahwa dasar pengeluaran suatu fatwa ialah setelah meneliti secara tuntas dasar-dasar atau argumen-argumen dari Alqur'an, hadis, ijma', dan qiyas, dengan urutan seperti itu. Di dalam kenyataan prosedur itu tidak diikuti secara konsisten. Ada fatwa yang langsung saja melihat hadis tanpa meninjau argumen Alqur'an terlebih dahulu, ada pula yang langsung saja mengutip teks sesuatu kitab fiqh tanpa melihat tiga sumber sebelumnya, bahkan ada pula fatwa yang tidak memberikan argumen sama sekali dan langsung saja kepada pernyataan fatwa itu sendiri. ${ }^{11}$

Sementara itu harus dipegangi pula prinsip-prinsip istidlal dalam menetapkan hukum yaitu; pertama, mengacu pada Alqur'an sebagai sumber utama (sumber dari segala sumber dalam hukum Islam). Kedua, merujuk ke sunnah sebagai penjelas Alqur'an, disamping sebagai penetap hukum manakala Alqur'an tidak menentukan hukumnya. Ketiga, terhadap nash yang mengandung dalalah zanniyah dilakukan ijtihad. Keempat, dalam menghadapi dua atau beberapa dalil kekuatannya sama dan zahirnya bertentangan (ta'arrud al-adilah), maka diambil jalan: (a) melakukan pengumpulan isi kandungan dalil, sehingga dapat diamalkan semuanya; (b) terhadap dalil Sunnah, dapat dilakukan penelitian waktu wurudnya dan yang lebih dahulu dinasakh (dihapus) dengan yang datang kemudian; (c) apabila tidak dapat dikumpulkan dan tidak dapat dinyatakan adanya nasakh mansukh, maka dilakukan tarjih. ${ }^{12}$

Seperti yang telah disebutkan di atas, bahwa dalam penetapan fatwanya, Ulama Indonesia hendaknya meyelaraskan setiap produk hukum sehingga bisa dipakai dan digunakan oleh berbagai golongan dan

${ }^{10}$ Abd. Arif Salam, Pembaruan Pemikiran Hukum Islam Antara Fakta dan Realita: Kajian Pemikiran Hukum Syaikh Mahmud Syaltut, (Yogyakarta: LESFI, 2003), h. 15.

${ }^{11}$ H. M. Atho Mudzhar, Membaca Gelombang Ijtihad: Antara tradisi dan Liberasi, (Yogyakarta: Titian Ilahi Press, 1998) h. 133.

${ }^{12}$ Abd. Arif Salam, Pembaruan Pemikiran Hukum Islam Antara Fakta dan Realita: Kajian Pemikiran Hukum Syaikh Mahmud Syaltut, h. 21. 
pihak, namun hendaknya MUI sendiri hendaknya menggaris bawahi penyelarasan keputusan hukum tersebut, sehingga tidak terjadi benturan antara hukum itu sendiri. Hal ini sebagaimana diungkapkan oleh Atho Mudzhar yang sedikit mengkritisi MUI yang mengambil keputusan fatwa yang selain dalam fatwanya mengambil pertimbangan-pertimbangan murni keagamaan, ada beberapa faktor sosial dan politik yang ikut melatarbelakangi lahirnya fatwa-fatwa tersebut: Pertama, ialah faktor keinginan MUI untuk turut menunjang kebijakan pemerintah. Fatwa tentang pembudidayaan kodok adalah contoh kuat dalam hal ini, di mana MUI mengharamkan hukum memakan kodok tetapi menghalalkan pembudidayaan yang ketika itu sedang digalakkan pemerintahan. Selain fatwa itu dipandang melakukan talfiq (karena mengambil pendapat mazhab Syafi'i untuk keharaman memakannya dan mazhab Maliki untuk kehalalan pembudidayaannya), oleh banyak pihak fatwa itu juga dipandang tidak mempunyai integritas karena seolah-olah biar saja orang lain yang memakan kodok itu asalkan kita sendiri tidak memakannya bahkan mendapatkan uang daripadanya. Begitulah kuatnya pengaruh keinginan untuk turut mendukung kebijakan pemerintah itu dalam fatwa tersebut. ${ }^{13}$ Independensi kekuasaan MUI dalam mengeluarkan fatwa merupakan salah satu hal yang amat penting di dalam penetapannya sebagai sebuah Ijtihadi. Tetapi yang terjadi antara idealisme dan realitasnya perlu adanya sebuah independensi, ditandai oleh adanya kehendak bagi kemandirian eksistensi MUI agar bekerja secara tidak memihak dan bebas dari intervensi politik. Faktor untuk mendukung kebijakan pemerintahan inilah yang membuat MUI belum bisa independen dalam mengeluarkan Ijtihad. Karena itulah, Buya Hamka menggambarkan bahwa jika tidak bekerja sungguh-sungguh MUI akan menghadapi berbagai kesulitan. Kedudukan ulama yang diharapkan menjadi penghubung antara kebijakan pemerintah dan aspirasi masyarakat memang serba sulit. ${ }^{14}$

Kedua, Faktor yang kedua yang mempengaruhi fatwa-fatwa MUI, yaitu keinginan untuk menjawab tantangan perkembangan zaman modern. Faktor ini sebagai usaha MUI untuk menjawab tantangan tersebut, tetapi disisi yang lain menyebabkan fatwa-fatwa yang independen itu jatuh sama dengan keinginan pemerintah. Ketiga,

\footnotetext{
${ }^{13}$ H. M. Atho Mudzhar, Membaca Gelombang Ijtihad: Antara tradisi dan Liberasi, h. $137-138$.

${ }^{14}$ Mahfud, Moh. MD, Pergulatan Politik dan Hukum di Indonesia, h. 259.
} 
menyangkut hubungan antar agama, atau lebih tepatnya adalah faktor keinginan untuk memelihara aqidah umat Islam dari segi kuantitas. ${ }^{15}$

Dari realitas yang mempengaruhi fatwa MUI, dapat dilihat bahwa hukum sebagai produk politik. Di kalangan ahli hukum minimal ada dua pendapat mengenai hubungan kausalitas antara politik dan hukum. Kaum idealis yang lebih berdiri pada sudut das sollen mengatakan bahwa hukum harus mampu mengendalikan dan merekayasa perkembangan masyarakat, termasuk kehidupan politiknya. Penulis seperti Roscue Pound telah lama berbicara "law as a tool of social engineering". Sebagai keiginan tentu saja wajar jika ada upaya untuk meletakkan hukum sebagai penentu arah perjalanan masyarakat karena dengan itu fungsi hukum untuk menjamin ketertiban dan melindungi kepentingan masyarakatnya akan menjadi lebih relevan. Tetapi kaum realis seperti Savigny mengatakan bahwa "hukum selalu berkembang sesuai dengan perkembangan masyarakatnya". Ini berarti bahwa hukum, mau tidak mau, menjadi independent variable atas keadaan di luarnya, terutama keadaan politiknya. ${ }^{16}$

\section{Dinamika Dalam Penerapan Hukum Islam di Indonesia}

Hukum Islam yang sudah berusia kurang lebih 14 abad, sejak beberapa abad yang akhir-akhir ini menjadi tersisih kedudukannya sebagai hukum positif di beberapa Negara, bukanlah satu hal yang mudah. Karena sebagaimana diakui oleh banyak ahli hukum Islam sendiri, seakan-akan tidak ada lagi satu bagianpun di dunia Islam sendiri yang rakyatnya sepenuhnya hidup menurut ajaran-ajaran Islam/Hukum Islam. ${ }^{17}$

Penerapan hukum Islam atau syariah sebetulnya bukanlah hal baru. Ia telah sejak lama dipraktekkan oleh beberapa negara Muslim, seperti Arab Saudi, Afghanistan dan Sudan. Pada tingkat lokal, syariat Islam juga diberlakukan di Zamfara, sebuah provinsi di Nigeria. Undangundang Islam di negara-negara ini secara keras diberlakukan, terutama menyangkut hukum pidana (hudud). Agaknya, persoalan pidanalah yang menjadi ciri khas apakah sebuah negara muslim dianggap menerapkan syariat Islam atau tidak. Dalam sistem hukum Indonesia, dikenal berbagai sumber hukum nasional yang berasal dari hukum adat, hukum Islam dan

\footnotetext{
${ }^{15}$ H. M. Atho Mudzhar, Membaca Gelombang Ijtihad: Antara tradisi dan Liberasi, h. 141 .

${ }^{16}$ Mahfud, Moh. MD, Pergulatan Politik dan Hukum di Indonesia, h. 71.

${ }^{17}$ Hazairin, Hukum Islam dan Masyarakat, Cetakan kedua, 1960.
} 
hukum barat. Ketiga sumber hukum tersebut selalu berlomba untuk mejadi hukum nasional sehingga berlakulah berbagai teori hukum. ${ }^{18}$

Syariat Islam adalah wahyu Allah yang diturunkan kepada Rasulullah untuk disampaikan kepada umatnya. Ia bukan sebuah teori, tetapi merupakan ajaran ilahi yang harus dipalajari, dan diberlakukan untuk menciptakan keteraturan dalam kehidupan masyarakat serta keseimbangan antara kewajiban dan hak. Syariat Islam akan berlaku bagi semua umat manusia di dunia sampai akhirat, tetapi bila syariat Islam dijadikan hukum positif disuatu negara, maka keberlakuannya hanya bagi masyarakat Islam. Ajaran tentang penataan hukum dalam kajian ilmu hukum memang merupakan sebuah teori yang dikemukakan oleh ahli hukum berdasarkan proses hukum yang terjadi di masyarakat, tetapi dari segi syariat Islam hal itu tidak saja disebut sebagai teori, melainkan merupakan prinsip yang wajib diberlakukan. ${ }^{19}$ Secara konseptual terdapat prinsip-prinsip syariat Islam yang mencakup penataan dan penerapan hukum Islam bagi orang Islam. Bahwa Allah dan Rasul-Nya memerintahkan kepada orang yang beriman agar menjalankan hukumnya. ${ }^{20}$

Para ahli hukum di Indonesia mempelajari tentang teori-teori penerapan hukum Islam melalui sistem hukum yang pernah berlaku di Indonesia selama masa kolonial Belanda. Adanya teori-teori ini menggambarkan, betapa akrabnya hukum Islam dengan penduduk, masyarakat, dan bangsa Indonesia. Hal ini merupakan indikator bagaimana perjuangan masyarakat Indonesia yang beragama Islam ingin memberlakukan syariat Islam sesuai perintah Allah dan rasul-Nya. ${ }^{21}$

Persoalan seputar penting tidaknya syariat Islam dilegislasikan menjadi hukum nasional merupakan satu wacana yang kerap melahirkan perdebatan yang cukup panjang. Pemikiran kearah itu banyak disampaikan oleh berbagai kalangan, walaupun dapat dipastikan bahwa pendapat para ahli tersebut banyak dipengaruhi oleh faktor-faktor politis, sosiologis, kultural, ideologis, dan religiositas.

${ }^{18}$ A. Rahmat Rosyadi, dan H. M. Rais Ahmad, Formalisasi Syariat Islam dalam Perspektif Tata Hukum Indonesia, (Edisi: I, Ghalia Indonesia, Bogor, April 2006), h. 9

${ }^{19}$ H. Ichtijanto S.A, Pengembangan Teori Berlakunya Hukum Islam di Indonesia, dalam: Hukum Islam di Indonesia, Perkembangan dan Pembentukan, (Remaja Rosdakarya, Bandung, 1991), h. 95-149.

${ }^{20}$ A. Rahmat Rosyadi, dan H. M. Rais Ahmad, Formalisasi Syariat Islam dalam Perspektif Tata Hukum Indonesia, h. 67.

${ }^{21}$ A. Rahmat Rosyadi, dan H. M. Rais Ahmad, Formalisasi Syariat Islam dalam Perspektif Tata Hukum Indonesia, h. 68. 
Azyumardi Azra ${ }^{22}$ misalnya, dalam menanggapi soal kemungkinan positifasi syariat Islam menjadi hukum nasional, mengungkapkan bahwa, yang harus diperhatikan adalah kondisi umat Islam Indonesia yang bukan merupakan realitas monolitik, tapi adalah realitas yang beragam, banyak golongannya, pemahaman keislamannya, keterikatannya, dan pengetahuannya yang berbeda-beda. Realitas sosilogis ini dikhawatirkan akan menimbulkan persoalan viabilitas. Artinya hukum Islam tersebut tidak bisa bertahan, bahkan mungkin juga bisa menjadi kontraproduktif ketika lapisan masyarakat Muslim yang pemahamannya terhadap Islam berbeda tadi kemudian tidak sebagaimana yang diharapkan.

Selain itu, menurut Azyumardi Azra, perbedaan mazhab fikih juga perlu diperhitungkan, karena harus kita akui bahwa di dalam soal fikih, khususnya mengenai hudud, terdapat perbedaan yang dari dulu sampai sekarang belum teratasi. Jadi, ada masalah secara internal di dalam fikih itu sendiri. Misalnya soal hudud, atau lebih spesifik lagi soal hukum rajam. Ada kalangan ulama misalnya Mahmud Syaltut berpendapat, hukum rajam adalah hukuman maksimal. Padahal kalau hukum rajam itu menjadi hukum yang maksimal, maka salah satu filsafat hukum yang merupakan inti dari filsafat hukum adalah menghindari semaksimal mungkin hukum yang maksimal. Karena kalau hukuman maksimal dijatuhkan maka fungsi aspek edukatif dari hukum itu menjadi hilang. Itu satu contoh yang perlu dipertimbangkan.

Merespon wacana dijadikannya hukum Islam sebagai penunjang pembangunan dalam kerangka sistem hukum nasional, Juhaya S. Praja mengatakan bahwa, walaupun dalam praktek tidak lagi berperan secara menyeluruh, hukum Islam masih memiliki arti besar bagi kehidupan pemeluknya. Setidaknya, ada tiga faktor yang menurut Praja, hukum Islam masih memiliki peranan besar dalam kehidupan bangsa. Pertama, hukum Islam telah turut serta menciptakan tata nilai yang mengatur kehidupan umat Islam, minimal dengan menetapkan apa yang harus dianggap baik dan buruk, apa yang menjadi perintah, anjuran, perkenaan, dan larangan agama. Kedua, banyak keputusan hukum dan yurisprudensial dari hukum Islam telah diserap menjadi bagian hukum positif yang berlaku. Ketiga, adanya golongan yang masih memiliki aspirasi teokratis dikalangan umat Islam sehingga peranan hukum Islam secara penuh masih menjadi slogan perjuangan yang masih mempunyai pengaruh cukup besar..$^{23}$

\footnotetext{
${ }^{22}$ Lihat, wawancara Azyumardi Azra, dalam http://www.islamlib.com

${ }^{23}$ Juhaya S. Praja, Hukum Islam di Indonesia, Pemikiran dan Praktik, (Rosda Karya, Bandung, 1991), h. xv.
} 
Oleh karena itu setidaknya ada beberapa hal yang menjadi modal atau kekuatan dalam usaha menuju penerapan syariat Islam;24

1. Jumlah umat Islam cukup signifikan.

2. Maraknya gerakan-gerakan Islam yang senantiasa menyuarakan diterapkannya syariat Islam.

3. Gagalnya beberapa sistem hukum dan bernegara yang bukan Islam telah memunculkan rasa frustasi umat manusia, sehingga mereka membutuhkan alternatif-alternatif yang lain. Diantara alternatif itu ialah Islam.

4. Keberhasilan usaha-usaha politik dari kalangan Islam dan partai-partai politik Islam di beberapa negeri Muslim.

5. Sejarah umat Islam yang cemerlang di masa lampau ketika mereka menerapkan syariat Islam. Sejarah cemerlang ini setidak-tidaknya bisa memunculkan kerinduan-kerinduan pada benak umat Islam atas kembalinya masa kejayaan mereka.

Sedangkan Secara umum hambatan-hambatan yang ada adalah sebagai berikut. ${ }^{25}$

1. Hambatan eksternal berupa pihak-pihak yang memang sejak awal memiliki antipati terhadap Islam dan syariat Islam. Mereka adalah para pengusung agama dan ideologi tertentu diluar Islam, terutama yang memiliki pengalaman pahit melawan Islam. Mereka senantiasa menyebarluaskan imej yang negative tentang Islam dan syariat Islam, misalnya dengan menjelek-jelekkan Islam dengan slogan "Harem dan Pedang" (sebagai simbol bagi pengungkungan kaum wanita dan kekerasan).

2. Hambatan dari pihak-pihak yang sebetulnya tidak terlalu ideologis kecuali bahwa mereka menolak penerapan syariat Islam karena akan mengekang kesenangan mereka. Mereka itulah yang sering disebut sebagai para hedonis, atau yang dalam bahasa Islam disebut sebagai ahlul ma'aashiy.

3. Hambatan dari pihak-pihak yang menolak syariat Islam karena belum memahami syariat Islam, atau memahaminya dengan pemahaman yang salah. Mereka inilah yang dalam bahasa Islam disebut sebagai ahlul jahl.

4. Disamping itu, usaha-usaha menuju penerapan syariat Islam juga berkaitan dengan masalah strategi. Hambatan-hambatan bisa pula muncul dari pihak-pihak yang sudah sepakat dengan syariat Islam dan penerapannya, akan tetapi memiliki strategi yang berbeda-beda.

\footnotetext{
${ }^{24}$ www.menaraislam.com, Strategi Menuju Penerapan Syariat Islam.

${ }^{25}$ www.menaraislam.com, Strategi Menuju Penerapan Syariat Islam.
} 
Hambatan dari sisi ini akan menjadi semakin signifikan apabila strategi-strategi tersebit saling berseberangan satu sama lain.

\section{Daftar Pustaka}

Azizy, A. Qodri A. Modern Scientific Ijtihād Bagian Pertama, disampaikan dalam seminar umum, Jakarta, t.th.

A. Rahmat Rosyadi, dan H. M. Rais Ahmad, Formalisasi Syariat Islam dalam Perspektif Tata Hukum Indonesia, Edisi: I, Ghalia Indonesia, Bogor, April 2006

Hasbi al-Șiddieqy,Teungku Muhammad, Pengantar Hukum Islam, Cet. I, Semarang, PT. Pustaka Rizki Putra, 1997

Haroen, Nasrun Ușūl Fiqih, Cet. I, Ciputat, Logos Publishing House, 1999

Ibn Hasan al-Jaizani Muhammad Ibn Hussain, Mu'ālim Ușūl al-Fiqh 'inda Ahlu Sunnah wa al-Jamā'ah, Cet. I, Riyadh, Dār al-Ibn al-Jauzi, 1996

Ibnu Hajār, Ijtihād La Yanquḍu Bil Ijtihād, Kairo, tt

Khadìm al-Haramain al-Syarifain, Al-Qur'an dan Terjemahan Maknanya

Maimun, Teori Qaț'i dan zannī Dalam Perspektif Hukum Keluarga Islam, Makalah Presentasi Dosen Fakultas Syari'ah IAIN Raden Intan Lampung, tidak diterbitkan.

Moh. MD, Mahfud, Pergulatan Politik dan Hukum di Indonesia, Yogyakarta: Gama Media, 1999

Muhammad al-Muḥtār al-Syātibi Muhammad al-Amīn ibnu, Muẓakkarah Fï Ușūl al-Fiqh, Madïnah al-Munawwarah, Maktabah al-Ulūm wa al-Hikam, t.th

Samsuddin Ibn mahmūd Abdu al-Rahmān al-Asfaḥāni, Syarḥu al-Manhāj lï al-Baiḍāwi Fỉ Ilmi al-Uṣūl, Jilid II, Riyād, Maktab al-Rusyd, 1999

Salam, Abd. Arif, Pembaruan Pemikiran Hukum Islam Antara Fakta dan Realita: Kajian Pemikiran Hukum Syaikh Mahmud Syaltut, Yogyakarta: LESFI,2003

Shuhufi, Muhammad, "Pengantar" Ijtihād dan Fleksibilitas Hukum Islam, Cet.I, Makassar: Alauddin University Press, 2012

Mudzhar, H. M. Atho, Membaca Gelombang Ijtihad: Antara tradisi dan Liberasi, Yogyakarta: Titian Ilahi Press,1998

Hazairin, Hukum Islam dan Masyarakat, Cetakan kedua, 1960.

H. Ichtijanto S.A, Pengembangan Teori Berlakunya Hukum Islam di Indonesia, dalam: Hukum Islam di Indonesia, Perkembangan dan Pembentukan, Remaja Rosdakarya, Bandung, 1991

Juhaya S. Praja, Hukum Islam di Indonesia, Pemikiran dan Praktik, Rosda Karya, Bandung, 1991 